\title{
ACRL
}

\section{Guidelines for Instruction Programs in Academic Libraries}

\section{The final version approved by ACRL and ALA}

$\mathbf{L}$ ibraries work together with other members of the education community to participate in and realize the educational mission of the institution by teaching the identification, structure, intellectual access, and physical access of information, information sources, and information systems through the design and development of instruction programs and services. Planning for the systematic delivery of instructional services should be incorporated throughout the library's activities, including the library's comprehensive planning and budgeting process. In order to best assist academic and research librarians in the preparation and development of effective instructional programs, the following guidelines are recommended.

\section{Program design}

\section{A. Statement of purpose}

The library should have a written statement of purpose for its instruction program that: articulates its purpose of the instruction program with respect to the educational mission of the institution and the needs of the learning community; involves the academic community in the formulation of these goals; recognizes the heterogeneous nature of the learning community through the identification of varieties of learning styles, attitudes, education levels, and local settings and environments; recognizes that instruction programs not only prepare learners for immediate curricular activities, but also enable them to be effective lifelong users of information in its many forms and contexts; and reflects changes in the institution and learning community through periodic revision.

\section{B. Identification of content of instruction}

While each institution will determine instructional content based on the needs of its clientele, the library should have a clearly articulated focus with projected outcomes. For guidance in the selection of content of instruction, see the "Model Statement of Objectives for Bibliographic Instruction" (CERL News, May 1987).

\section{Identyfication of modes of instruction}

Instruction takes place in many ways using a variety of teaching methods. These may include, but are not limited to: advising individuals at reference desks, in-depth research consultations, individualized instruction, electronic or print instruction aids, or group instruction in traditional or electronic classroom settings. The mode(s) selected should be consistent with the content and goals of instruction. Where appropriate, more than one mode of instruction should be used in recognition of the wide variety of learning styles of individuals. For suggestions and explanations of modes of instruction, see the Sourcebook for Bibliographic Instruction.

\section{Evaluation and assessment}

Evaluation and assessment are systematic ongoing processes that should gather data to inform decision-making regarding the instruction program. Data gathered should give an indication that the instruction program is supporting the goals set forth in its "Statement of Purpose for Instruction." See the Evaluation Handbook for guidance. The evaluation or assessment plan should delineate exactly what measures are taken and who is involved in the assessment. The program should consider as many measures as pos- 


\section{Developing the Guidelines}

In 1977 ACRL approved the "Guidelines for Bibliographic Instruction in Academic Libraries" as the standard and guideline for instruction programs generally. This first document was intended to provide a framework for developing, evaluating, and ultimately institutionalizing instructional programs and services in college and research libraries and to assist any library or librarian seeking to build or maintain an instructional service. The 1977 "Guidelines" were written by the Bibliographic Instruction Task Force and published in the BIS Handbook.

In 1987 the revision of the "Model Statement of Objectives for Academic Libraries" made the BIS Handbook obsolete. The 1977 "Guidelines" were maintained as a separate and important document which sought to outline the programmatic needsincluding staffing, facilities, and budgeting - of instructional services. In 1993, after a survey of membership, it was determined that the "Guidelines" should be revised to reflect the maturation of instruction programs generally and, perhaps more important, the impact that new technologies and changing campus environments have placed on instruction programming. A task force was formed at that time to incorporate these new concerns into

sible. These measures may include, but are not limited to needs assessment, participant reaction, learning outcomes, teaching effectiveness, and overall effectiveness of instruction. The criteria for evaluation should be articulated. The assessment program should incorporate a variety of methods and instruments. The data should be gathered at intervals consistent with the revision process so that current information is cycled into the ongoing planning process.

\section{Human resources}

To achieve the goals set forth in the library's instruction statement of purpose, the library should employ or have access to sufficient personnel with appropriate education, experience, and expertise to: teach individuals and groups in the campus community; design a variety of instruction programs and services; promote, market, manage, and coordinate diverse instruction activities; collect and interpret assessment data to evaluate and update instruction programs and services; integrate and apply instruction technologies into learning activities; produce instruction materials using available media and electronic technologies; participate in campus and faculty groups, committees, and departments that plan and execute education activities; and respond to changing technologies, environments, and communities. the "Guidelines" which recognizes the need to as sess achievement of instructional goals.

In the development of the revised "Guidelines" which appear below, the task force was guided by the following principles: instruction programming is an essential and fundamental educational service which should be made available by academic libraries to their primary clientele; advances in technology should augment and enhance, not replace, the instruction department and programming of an institution; the diversity of clientele mandates that issues such as the format, mode of instruction, content, method of delivery, and assessment of programs should be decisions that are made at the institutional level and reflect the heterogeneous nature of that clientele.

As such, the "Guidelines" do not delineare specific recommendations for types of programming. Rather they focus on the process and support procedures that should be used to make these decisions. The "Guidelines" were the focus of an open forum held at Midwinter 1996, and were approved by the ACRL Board at Annual 1996. The ALA Standards Committee approved them at the 1997 Midwinter Meeting.

\section{Support}

Support for a successful instruction program has many interdependent facets. The level of support necessary will depend on the scope and size of the program.

\section{A. Instruction facilities}

The library should have, or should have ready access to, facilities of sufficient size and number that are equipped to meet the goals of the instruction program and reach the instructional learning community. The instructional setting(s) should duplicate the equipment and technology that is available to users. At minimum, the facilities should allow the instructor to demonstrate information systems available to the library's users. It is desirable that the facilities provide individual hands-on experience for those being instructed. The instructional setting should be flexible enough to accommodate a variety of teaching methods and learning styles.

\section{B. Staff work facilities}

The library should provide convenient access to the equipment and services necessary to design, produce, reproduce, and update instruction materials in a variety of formats. The library should provide sufficient space for the preparation and storage of instruction materials. 


\section{Financial support}

The instruction program should have adequate funds identified to attain the stated goals of the program. The funding for an instruction program should cover all personnel costs connected with the program, including but not limited to student, clerical, and technical assistance. The funding should cover supplies and materials; equipment or access to equipment; design, production, reproduction, and revision of materials; promotion and evaluation of the instruction program; as well as other identified costs. The allocation process should allow for equipment and software replacement and enhancement as changes occur. The funding should provide for training and continuing education of those involved in the instruction program.

\section{Support for staff continuing education, training, and development}

Nonmonetary support for continuing staff development helps to establish an atmosphere conducive to innovation and high morale. It is recommended that the library: provide staff members with a written description of the scope of their instructional responsibilities; provide a structured program for orientation and training of new instruction personnel (see the publication Learning to Teach for suggestions); and develop a program of continuing education or make available continuing education opportunities.

\section{Supporting documents}

Evaluation Handbook (pub. forthcoming).

Learning to Teach: Workshops on Instruction, edited by Ellen Broidy, Joan Kaplowitz, Kari Lucas, Susan Miller, Billie Peterson, and Thomas Zogg, Chicago: ALA, ACRL, BIS, 1993.

"Model Statement of Objectives for Academic Bibliographic Instruction: Draft Revision," edited by Lori Arp, Barbara Beaton, Joseph Boisse, Julie Cizny, David Ginn, Roland Person, Jan Rice, and Beth Woodard, CERL News (May 1987) 48(5): 256-261.

"Model Statement of Objectives for Academic Bibliographic Instruction," in Read This First: An Owner's Guide to the New Model Statement of Objectives for Academic Bibliographic Instruction, edited by Carolyn Dusenbury, Monica Fusich, Kathleen Kenny, and Beth Woodard. Chicago: ALA, ACRL, BIS, 1991.

Sourcebook for Bibliographic Instruction, edited by Katherine Branch, Carolyn Dusenbury, Barbara Conant, Cynthia Roberts and Kimberly Spyers-Duran, Chicago: ALA, ACRL, BIS, 1993.

\section{C\&RL News 30th anniversary quiz}

Here is the next installment of the CERL News 30 th anniversary quiz. Test your recollection of events that have been reported in the News since 1966.

\section{How much did the federal government} spend on libraries per person in 1995?

2. What is the British counterpart to CGRL News?

3. In the 1960s, West Virginia's most famous author gave a copy of her new biog- raphy to the state's oldest educational institution to bring its library collection to the 100,000 mark. Name this celebrated author and the institution.

4. When did the American Mathematical Society name an Ad Hoc Library Committee to study library issues that affect the mathematics research community?

5. How did the library at Butler University manage to get incoming freshman into the library before classes started?

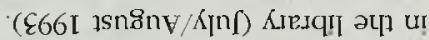

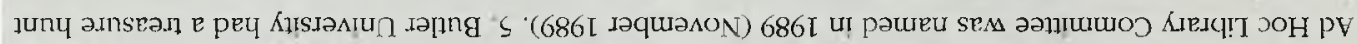

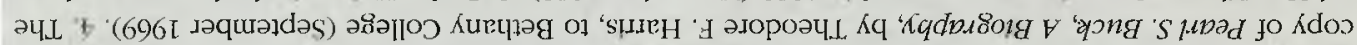

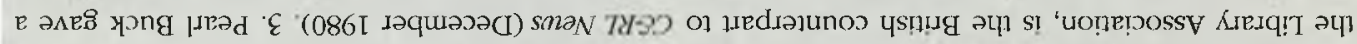

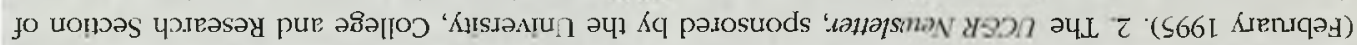

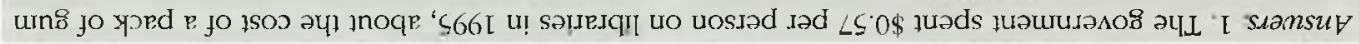




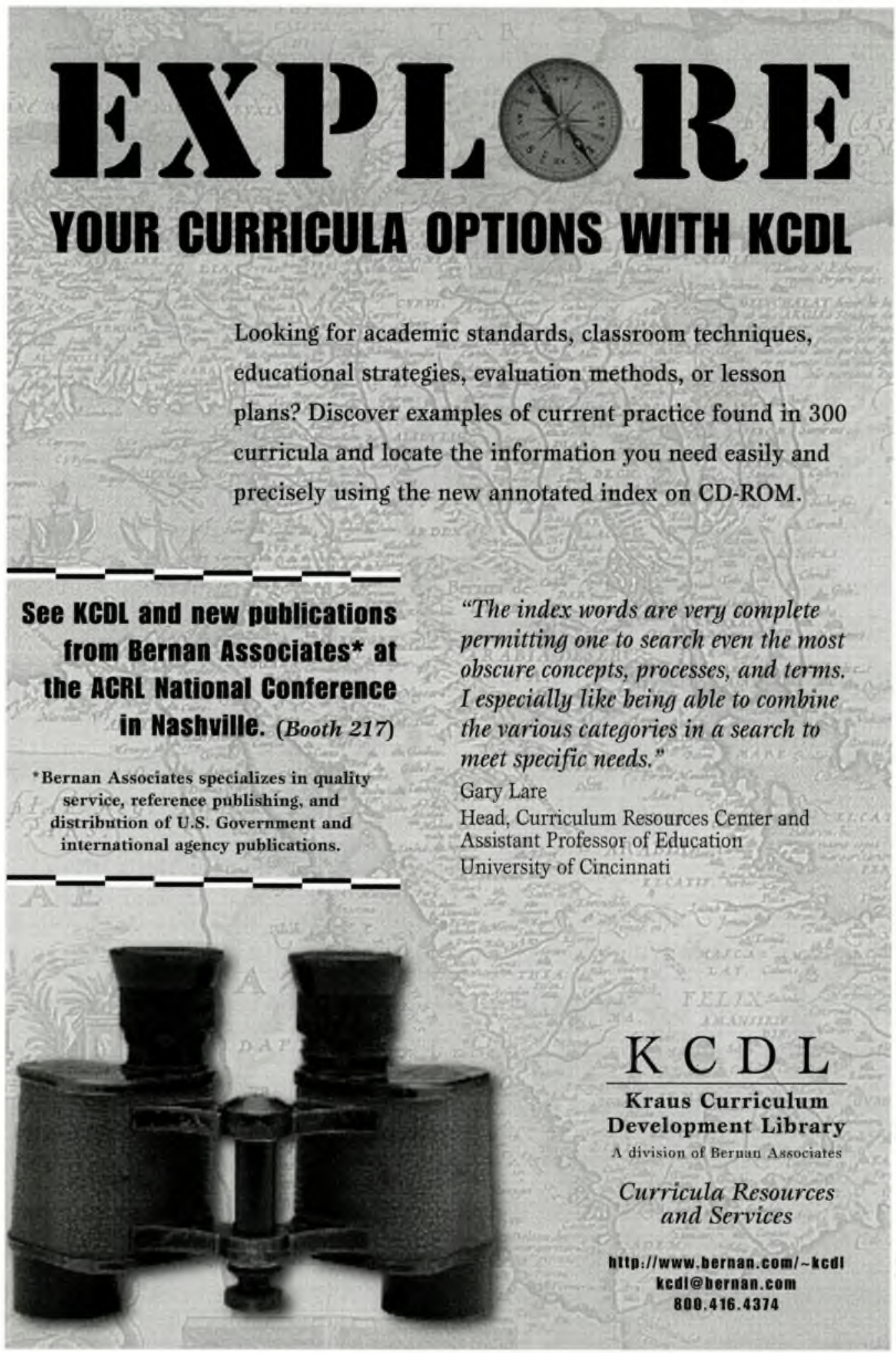




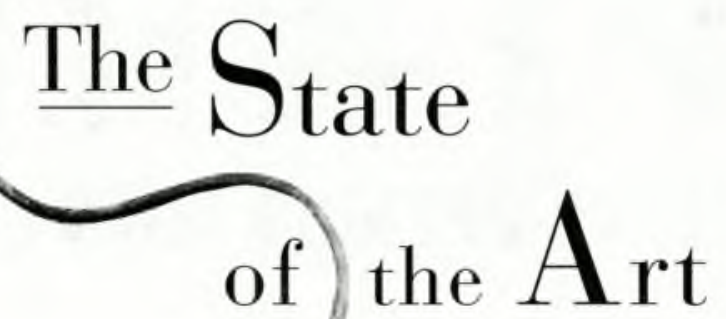

Information industry leaders in providing subscription services, article delivery \& library automation soffware.

ROSS ${ }^{\circledR}$ Online ordering, claiming and searching of journal and publisher databases.

Remo ${ }^{\mathbb{B}}$ Mouse driven serials management system.

Electronic Interfaces \& Customized Automated Management Products

ReadiCat Our comprehensive Internet catalog of serial titles searchable by a number of access points.

...working smart

\section{Backserv/BackMed}

Internet lists solely devoted to the informal exchange of serial back issues among libraries.

\section{World Wide Web} http://www.readmore.com

READMORE, INC.

22 Cortlandt Street

New York, NY 10007
Phone: 1-800-221-3306

Fax: 212-233-0746 